\title{
Punctual mutations in lipoxygenase sequence expressed in black soybean seed coat ${ }^{1}$
}

\author{
Liliane Marcia Mertz ${ }^{2 *}$, Fernando Augusto Henning ${ }^{3}$, Ana Paula Piccinin Barbieri², \\ Samantha Rigo Segalin ${ }^{2}$, Francisco Carlos Krzyzanowski ${ }^{3}$, Paulo Dejalma Zimmer ${ }^{4}$
}

\begin{abstract}
Lipoxygenase enzymes are relevant in several characteristics of soybean seeds, such as germination performance, storage capacity and tolerance to infection by microorganisms. In this sense, the study of allelic variations of the genes related to that enzyme may be promising for the development of molecular markers associated with phenotypic characteristics which are relevant to seed physiology. This study aimed to identify mutations in lipoxygenase sequence expressed in black soybean seed coat. After isolation of the sequence of interest by the cDNA-AFLP technique, such sequence was compared with sequences of nucleotides and proteins of the lipoxygenase present in yellow soybean seed coat. Analysis of multiple sequence alignment has shown an expressive number of changes in the sequence of nucleotides, which have resulted in the modification of 13 amino acids in the translated protein. The identification of such mutations widens the possibility for further studies involving the association of these allelic variations with phenotypic differences of interest to seeds physiology.
\end{abstract}

Index terms: Glycine max, molecular marker, enzymes.

\section{Mutações pontuais em sequências expressas da enzima lipoxigenase em tegumentos de sementes de soja de coloração preta}

\begin{abstract}
RESUMO - Enzimas lipoxigenases possuem relevância em diversas características das sementes de soja, como desempenho germinativo, capacidade de armazenamento e tolerância ao ataque de microrganismos. Nesse sentido, o estudo de variações alélicas de genes relacionados a essa enzima podem ser promissores para o desenvolvimento de marcadores moleculares relacionados a caracteres fenotípicos de interesse a fisiologia de sementes. Este trabalho objetivou identificar mutações em sequência de lipoxigenase expressa em tegumentos de sementes de soja de coloração preta. Após isolamento da sequência de interesse pela técnica de cDNA-AFLP, a mesma foi comparada com sequências de nucleotídeos e proteínas da lipoxigenase presente em sementes de soja de coloração amarela. A análise do alinhamento múltiplo entre as sequências mostrou um número expressivo de alterações na sequência de nucleotídeos, as quais resultaram na modificação de 13 aminoácidos na proteína traduzida. A identificação dessas mutações abre a possibilidade para estudos futuros envolvendo a associação dessas variações alélicas com diferenças fenotípicas para caracteres de interesse a fisiologia de sementes.
\end{abstract}

Termos para indexação: Glycine max, marcadores moleculares, enzimas.

\section{Introduction}

The lipoxygenase enzyme catalyzes the hydroperoxidation of polyunsaturated fatty acids (Vick and Zimmerman, 1981). Soybean seeds contain three lipoxygenases isozymes called Lipoxygenase 1 (L-1), Lipoxygenase 2 (L-2) and Lipoxygenase 3 (L-3) (Axelrod et al., 1981). It was suggested that products of the lipoxygenases can be metabolized and produce compounds with distinct functions during

${ }^{1}$ Submitted on 10/25/2012. Accepted for publication on 02/13/2013. ${ }^{2}$ Universidade Federal de Santa Maria, Departamento de Fitotecnia, 97105-900 Santa Maria, RS, Brasil.

${ }^{3}$ Embrapa Soja, Caixa Postal 231, 86001-970 - Londrina, PR, Brasil. germination, plant growth and development, as well as in the mechanisms of tolerance to pathogen infections (Dias et al., 2002; Akram et al., 2008).

Innumerous scientific studies have been performed aiming at investigating the effect of lipoxygenases in soybean seed performance. Negative effect of lipoxygenase was observed during soybean seed storage; however, in studies performed by Lima et al. (2010), it was observed that soybean seed deterioration was more influenced by the linolenic acid

${ }^{4}$ Universidade Federal de Pelotas, Departamento de Fitotecnia, 96010-900 Capão do Leão, RS, Brasil.

*Corresponding author < lilianemertz@yahoo.com.br.> 
content than by the lipoxygenase enzyme, since the vigor of the genotypes with low linolenic acid content was higher during storage.

In contrast, Oliveira et al. (2006) showed that the presence of lipoxygenase contributes to favor emergence speed of soybean seedlings. In germinating soybean seeds, lipoxygenases were found not to be involved in lipid mobilization (Wang et al., 1999). The lack of substantial oxygenation of polyunsaturated fatty acids during the germination process supports the idea that soybean seed lipoxygenases might have been recruited to function as storage proteins despite their intact but obsolete enzymatic capacity (Siedow, 1991; Wang et al., 1999; Lenis et al., 2010). The presence of lipoxygenase in the germinative process was also detected in studies carried out with pea seeds (Pisum sativum L), in which there is a shift of lipoxygenase activity from radicles to shoots that accompanies the transition from seed lipoxygenases to vegetative lipoxygenases (Mo and Koster, 2006).

Secondary metabolites, resulting from lipoxygenase activity, also play an important role in the defense against pathogens, even in seeds. In studies conducted by Gao et al. (2009), some maize mutant seeds, without lipoxygenase, presented higher susceptibility to different species of Aspergillus spp.

Among soybean genotypes, genetic variability indeed occurs for some seed characteristics, including those related to coat color (Mertz et al., 2010), which may be used in studies aiming at identifying allelic variations of interest genes, thus facilitating comprehension of the role of enzymes or proteins of importance to seed physiology, as lipoxygenase.

Thus, this study aimed to identify mutations in the lipoxygenase sequence expressed in soybean genotypes with black coat coloration.

\section{Material and Methods}

The lipoxygenase sequence from black soybean seed coat was obtained from the AFLP Starter Primer Kit (Invitrogen) primer combination EcoRI-AGC/MseI-CTC which generated 12 polymorfic fragments of cDNA - AFLP, differentially expressed between soybean seeds coats (Genotype TP) of black coat coloration and (cv. CD 202) of yellow coloration, as described by Mertz et al. (2010). One of the polymorphic fragments was aligned and showed high similarity with the lipoxygenase sequence. Afterwards, the same sequence was compared by means of global alignment with the lipoxygenase sequences deposited in data bank NCBI (Nacional Center for Biotechnology Information - http:/ www.ncbi.nlm.nih.gov/) in order to detect the occurrence of preserved blocks and the occurrence of mutation of the insertion/ deletion type (INDELS) or of simple nucleotide polymorphism (SNPs). This was done by associating software programs ClustalW (Thompson et al., 1994) and BioEdit 7.0.0 (Hall, 1999). After identifying the presence of mutations, the sequences were then translated into amino acids by using the software ExPASy Translate tool (Gasteiger et al., 2003) in (www.expasy.ch/tools/ dna.html) and aligned again by means of software programs ClustalW (Thompson et al., 1994) and BioEdit 7.0.0 (Hall, 1999). This was performed to verify if the changes in the nucleotides resulted in changes in the sequence of amino acids of the protein.

\section{Results and Discussion}

The analysis of the multiple alignments between lipoxygenase of soybean with yellow coat deposited in data bank and the sequence obtained within this study has shown an expressive number of changes in the sequence of nucleotides (Figure 1).

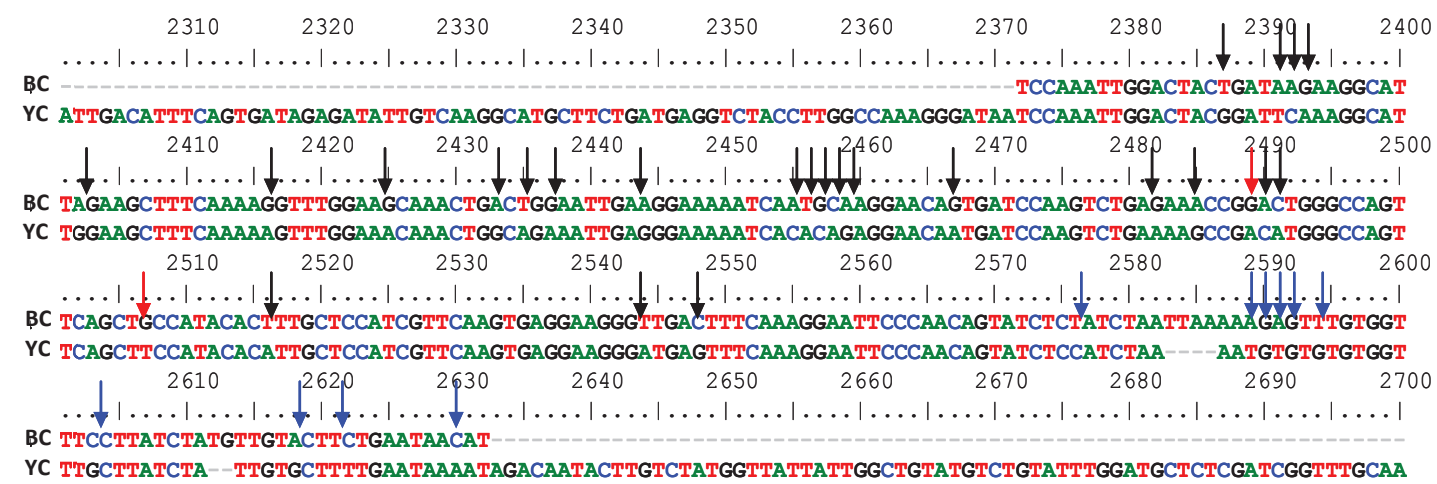

Figure 1. Global alignment between lipoxygenase nucleotides sequences expressed in black soybean seed coat (BC) and lipoxygenase sequence of soybean genotypes with yellow seed coat (YC) (Lipoxygenase (U26457.1) - Glycine max). Black arrows indicate changes of nucleotides that result in amino acid substitution; red arrows indicate silent mutations, and blue arrows indicate mutations that occur after codon determination. 
After the cDNA sequence of genotype BC was translated into amino acids and compared with the protein sequences deposited at data bank (Figure 2), the occurrence of mutations in 13 amino acids was observed along the alignment corresponding to 90 amino acids (Table 1).

From the 13 modified amino acids, eight were substituted by amino acids belonging to the same group; two amino acids were substitutions from the neutral polar group to the basic polar group, or vice-versa (Ser-Lys and His-Thr); two amino acids of the non-polar group were substituted by amino acids from the neutral polar group, or vice-versa (Ala-Thr and Gln-Ala); and one polar amino acid was substituted by another from the neutral polar group (Glu-Gly) (Table 1).

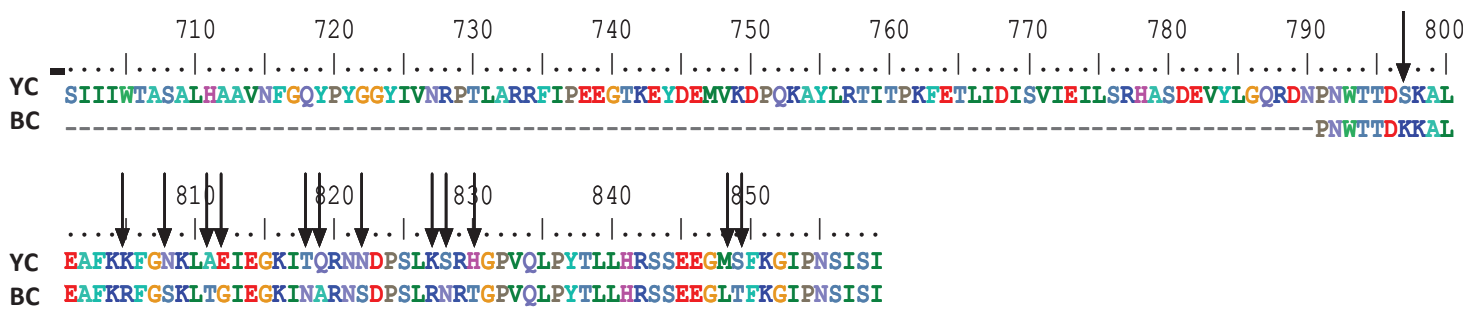

Figure 2. Global alignment between sequences of amino acids of the lipoxygenase protein (Lipoxygenase (U26457.1) - Glycine $\max$ ) and amino acids sequence translation expressed in black soybean seed coat. Arrows indicate the loci where amino acid substitution occurred.

Table 1. Changes in amino acid composition of the lipoxygenase protein expressed in the soybean seeds coats of black coloration. The different colors represent the groups sorted as a function of the radical: red (non-polar); blue (polar neutral); black (polar acid); and green (polar basic).

\begin{tabular}{llcc}
\hline \multicolumn{1}{c}{ Change of the amino acid } & \multicolumn{2}{c}{ Change of the codon } \\
\hline \multicolumn{1}{c}{ NCBI* } & cDNA & NCBI* & cDNA \\
\hline S serine (Ser) & K lysine (Lys) & UCA & AAG \\
k lysine (Lys) & R arginine (Arg) & AAG & AAC \\
N asparagine (Asn) & S serine (Ser) & GCA & ACU \\
A alanine (Ala) & T threonine (Thr) & GAA & GGA \\
E glutamic acid (Glu) & G glycine (Gly) & ACA & AAU \\
T threonine (Thr) & N asparagine (Asn) & CAG & GCA \\
Q glutamine (Gln) & A alanine (Ala) & AAU & AGU \\
N asparagine (Asn) & S serine (Ser) & AAA & AGA \\
K lysine (Lys) & R arginine (Arg) & AGC & AAC \\
S serine (Ser) & N asparagine (Asn) & AUG & ACU \\
H histidine (His) & T threonine (Thr) & AGU & UUG \\
M methionine (Met) & L leucine (Leu) & ACU
\end{tabular}

*NCBI (National Center for Biotechnology Information).

Such modifications may cause changes in the tridimensional structure of the protein and, consequently, its catalytic function (Skrzypczak-Jankun et al., 1997).

The phenotypic effects of these mutations are as much or more drastic, the bigger the difference in the chemical nature of the lateral chains of the amino acid residues; for example, the substitution of one hydrophilic amino acid (polar) by one amino acid with lateral chain of hydrophobic residue (nonpolar). This occurred when the substitution of Glutamine by Alanine (Gln - Ala), or yet when the substitution resulted in the inversion of the electric charge of the residue. In this study, the substitution of glutamic acid by glycine (Glu Gly) occurred, i.e., of one amino acid with negative charge by one neutral amino acid, that is, without electric charge.

SNP variations (Single nucleotide polymorphism) were identified in genes of the alpha amylase enzyme in different ecotypes of rice, aiming at associating these mutations with characteristics related to seed germination (Malone et al., 2008).

The role of LOXs in plants is ambiguous; some reports suggested that LOX and its hydroperoxide products might 
directly participate in senescence; however, data obtained by (Wang et al., 1990) suggested that LOX, especially LOX 2, may play an important physiological role in maintaining viability rather than promoting senescence of soybean seeds.

In addition, it was suggested that the lipoxygenases enzymes and their products may play a significant role in the seed germination process and in seed physiological quality (Dias et al., 2002; Oliveira et al., 2006). So, the identification of these expressed mutations in the sequence of lipoxygenases obtained in this study suggests the feasibility of further studies involving associations of these allelic variations with phenotypical difference for characteristics of interest to seed physiology, aiming at the development of molecular markers based on SNP.

\section{Conclusion}

Punctual mutations were identified in lipoxygenase sequences from black soybean seed coat.

\section{Acknowledgements}

The authors would like to thank FAPERGS and CNPq for their financial support.

\section{References}

AKRAM, A.; ONGENA, M.; DUBY, F.; DOMMES, J.; THONART, P. Systemic resistance and lipoxygenase-related defence response induced in tomato by Pseudomonas putida strain BTP1. BMC Plant Biology, v.8, n.113, 2008. http://www.biomedcentral.com/1471-2229/8/113

AXELROD, V.; CHEESBROUGH, T.M.; LAASKO, S. Lipoxygenase from soybeans. Methods in Enzymology, v.71, p.441-451, 1981.

DIAS, A.C.P.; REIS, M.S.; OLIVEIRA, M.G.A.; SEDIYAMA, C.S.; MOREIRA, M.A. Atividade de lipoxigenases durante a germinação de sementes de soja. Revista Ceres, v.49, n.284, p.419-30, 2002. http://www. ceres.ufv.br/ceres/revistas/v49n284p16602.pdf

GAO, X.; BRODHAGEN, M.; ISAKEIT, T.; BROWN, S.H.; GOBEL, C.; BETRAN, J.; FEUSSNER, I., KELLER, N.P.; KOLOMIETS, M.V. Inactivation of the lipoxygenase ZmLOX3 increases susceptibility of maize to Aspergillus spp. In: Molecular Plant Microbe Interactions, v.22, p.222-231, 2009.

GASTEIGER, E.; GATTIKER, A.; HOOGLAND, C.; IVANYI, I.; APPEL, R.D.; BAIROCH, A. ExPASy: the proteomics server for in-depth protein knowledge and analysis. Nucleic Acids Research, v.31, p.3784-3788, 2003.

HALL, T.A. BioEdit: a user-friendly biological sequence alignment editor and analysis program for Windows 95/98/NT. Nucleic Acids Symposium, 1999. 41p.
LENIS, J.M.; GILLMAN, J.D.; LEE, J.D.; SHANNON, J.G.; BILYEU, K.D. Soybean seed lipoxygenase genes: molecularcharacterization and development of molecular marker assays. Theorical and Applied Genetics, v.120, p.11391149, 2010. http://link.springer.com/article/10.1007\%2fs00122-009-1241-9

LIMA, W.A.A.; BORÉM, A.; DIAS, D.C.F.S.; MOREIRA, M.A.; DIAS, L.A.S. Lipoxygenase and physiological quality of soybean seeds during storage. Seed Science and Technology, v.38, n.3, p.767-771, 2010.

MALONE,G.;PESKE, S.T.;ZIMMER,P.D.;MALONE,E.;MENEGHELLO, G.E.; OLIVEIRA, C.A. Single nucleotide polymorphism (SNP) detection in the red rice $\alpha$-amylase gene amy1: effect on seedling vigor. Seed Science and Technology, v.36, n.2, p.447-445, 2008

MERTZ, L.M.; HENNING, F.A.; BORSUK, S.; MAIA, L.C.; DELLAGOSTIN, O.A.; PESKE, S.T.; ZIMMER, P.D. cDNA-AFLP analyses between black and yellow soybean seed coats. Seed Science and Technology, v.38, p.88-95, 2010.

MO, B.; KOSTER, K.L. Changes in lipoxygenase isoforms during germination and early seedling growth of Pisum sativum L. Seed Science Research, v.16, p.97-106, 2006.

NCBI. National Center for Biotechnology Information. http://www.ncbi.nlm. nih.gov. Accessed on: Jan. $13^{\text {rd }} 2012$

OLIVEIRA, D.A.; PIOVESAN, N.D.; JOSÉ, I.C.; BARROS, E.G.; DIAS, D.C.F.S.; MOREIRA, M.A. Lipoxigenases e teor de ácido linolênico relacionados à qualidade de sementes de soja. Revista Brasileira de Sementes, v.28, n.1, p.30-35, 2006. http://www.scielo.br/pdf/rbs/v28n1/a05v28n1.pdf

SIEDOW, J.N. Plant lipoxygenase: structure and function. Annual Reviews Plant Physiology Plant Molecular Biology, v.42, p.145-188, 1991. http:// www.annualreviews.org/doi/pdf/10.1146/annurev.pp.42.060191.001045

SKRZYPCZAK-JANKUN, E.; AMZEL, L.M.; KROA, B.A.; JR. FUNK, M.O. Proteins: Structure, Function and Genetic, v.29, p.15-31, 1997.

THOMPSON, J.D.; HIGGINS, D.G.; GIBSON, T.J. CLUSTAL W. Improving the sensitivity of progressive multiple sequence alignment through sequence weighting, position-specific gap penalties and weight matrix choice. Nucleic Acids Research, v.22, n.22, p.4673-4680, 1994. http://www.ncbi.nlm.nih. gov/pmc/articles/pmc308517/pdf/nar00046-0131.pdf

VICK, B.A.; ZIMMERMAN, D.C. Lipoxygenase, hydroperoxide isomerase and hydroperoxide cyclase in young cotton seedlings. Plant Physiology, v.67, p.92-97, 1981. http://www.plantphysiol.org/content/67/1/92.full.pdf

WANG, J.Y.; FUJIMOTO, K.; MIYAZAWA, T.; ENDO, Y.; KITAMURA, K. Sensitivities of lipoxygenase-lacking soybean seeds to accelerated aging and their chemiluminescence levels. Phytochemistry, v.29, n.12, p.3739-3742, 1990. http://www.sciencedirect.com/science/article/pii/0031942290853238

WANG, C.; CROFT, K.P.C.; JARLFORS, U.; HILDEBRAND, D.F. Subcellular localization studies indicate that lipoxygenases 1 to 6 are not involved in lipid mobilization during soybean germination. Plant Physiology, v.120, p.227-236, 1999. http://www.ncbi.nlm.nih.gov/pubmed/10318700 